UDK $577.1: 61$

ISSN 1452-8258

J Med Biochem 37: 465-469, 2018

Original paper

Originalni naučni rad

\title{
POTENTIAL PROGNOSTIC ROLE OF IMMUNE SYSTEM ACTIVATION MARKER NEOPTERIN IN PATIENTS WITH TYPE 2 DIABETES
}

\section{POTENCIJALNA PROGNOSTIČKA ULOGA MARKERA AKTIVACIJE IMUNOG SISTEMA NEOPTERINA KOD OBOLELIH OD TIPA 2 DIJABETESA}

\author{
Songül Ünüvar ${ }^{1}$, Zübeyde Tanrıverdi ${ }^{1}$, Hamza Aslanhan ${ }^{2}$ \\ ${ }^{1}$ Pharmaceutical Toxicology Department, Faculty of Pharmacy, Inönü University, Malatya, Turkey \\ ${ }^{2}$ Family Medicine Department, Faculty of Medicine, Dicle University, Diyarbakır, Turkey
}

\section{Summary}

Background: An increase in neopterin concentrations is known in some pathologies due to interferon-gamma (INF- $\gamma$ ) activation. These include viral and bacterial infections, autoimmune diseases, metabolic diseases, psychiatric disorders, tissue and organ rejections, and different malignancies. The aim of this study was to evaluate the role of neopterin as a prognostic biomarker in type 2 diabetes, which is a metabolic disease with a high worldwide prevalence.

Methods: The study included a total of one hundred thirtynine individuals including one hundred and six patients admitted to a family medicine outpatient clinic and diagnosed with type 2 diabetes and thirty-three healthy volunteers. Serum neopterin concentrations were measured using the enzyme-linked immunosorbent assay.

Results: Serum neopterin levels significantly increased in type 2 diabetes patients, compared to the control group $(\mathrm{p}<0.001)$.

Conclusions: Early diagnosis of diabetes and determination of the appropriate therapeutic options are of utmost importance, as diabetes is also associated with other systemic diseases. The risk of developing secondary diseases is high in untreated patients. Our study results suggest that serum neopterin may be a useful biomarker in patients with type 2 diabetes.

Keywords: type 2 diabetes, metabolic diseases, neopterin, immune system activation, interferon-gamma

\section{Kratak sadržaj}

Uvod: Poznato je da u nekim patološkim stanjima dolazi do porasta koncentracija neopterina usled aktivacije interferonagama (INF- $\gamma$ ). Ovde spadaju virusne i bakterijske infekcije, autoimune bolesti, metabolička oboljenja, psihijatrijski poremećaji, odbacivanje tkiva ili organa i različiti maligniteti. Cilj ove studije bio je da se odredi uloga neopterina kao prognostičkog biomarkera u tipu 2 dijabetesa, koji je metaboličko oboljenje sa visokom prevalencom širom sveta.

Metode: Studija je obuhvatila ukupno 139 osoba, među kojima 106 pacijenata primljenih u kliniku za porodičnu medicinu kod kojih je dijagnostikovan tip 2 dijabetesa i 33 zdravih dobrovoljaca. Koncentracije neopterina u serumu merene su metodom ELISA.

Rezultati: Nivoi neopterina u serumu značajno su porasli kod obolelih od tipa 2 dijabetesa u poređenju s kontrolnom grupom $(p<0,001)$.

Zaključak: Rana dijagnoza i određivanje odgovarajućih terapijskih mogućnosti su od presudne važnosti, pošto je dijabetes povezan i sa drugim sistemskim oboljenjima. Kod nelečenih pacijenata postoji veliki rizik od razvoja sekundarnih bolesti. Rezultati naše studije ukazuju na to da neopterin u serumu može biti koristan biomarker kod obolelih od tipa 2 dijabetesa.

Ključne reči: tip 2 dijabetesa, metabolička oboljenja, neopterin, aktivacija imunog sistema, interferon-gama

Address for correspondence:

Songül Ünüvar

Department of Pharmaceutical Toxicology,

Faculty of Pharmacy, Inönü University, Malatya, Turkey

Tel: +90 422341 0660; Fax: + 904223411217

e-mail: songul.unuvar@inonu.edu.tr 


\section{Introduction}

Globally, diabetes mellitus causes morbidity and mortality and its prevalence is increasing every year. According to the World Health Organization (WHO), an estimated 422 million diabetic adults were living with diabetes in 2014 worldwide. In addition, 2.2 million deaths due to high blood glucose and 1.6 million deaths directly associated with diabetes have been reported $(1,2)$.

According to the American Diabetes Association (ADA), diabetes can be classified into four subgroups as type 1, type 2, gestational diabetes (primary diabetes), and secondary diabetes (3). Diabetes is a metabolic disease characterized by hyperglycemia, which results from defects in insulin secretion, insulin resistance, or both (4).

In the vast majority of type 1 diabetic patients, there is autoimmune beta-cell destruction, and reduced insulin levels are observed due to this damage in beta cells (5). In type 2 diabetes, which is the most often diagnosed type and also referred to as non-insulin dependent diabetes mellitus (NIDDM), insulin secretion and insulin sensitivity of the target tissues decrease $(1,4,5)$. Thus, the risk of developing type 2 diabetes is high in patients with impaired glucose tolerance (IGT) and impaired fasting glycemia (IFG) (1).

Genetic predisposition, environmental factors, obesity, sedentary lifestyle, stress, polycystic ovary syndrome (PCOS), unhealthy eating habits and elderly can be listed among the causes of type 2 diabetes (4, 5). In patients with type 2 diabetes, complications such as polyuria, polydipsia, polyphagia and weight loss are frequently observed in addition to hyperglycemia (3, 5). Uncontrolled hyperglycemia leads to severe damage to almost all organs. Complications related to hyperglycemia and diabetes include cardiovascular diseases, diabetic retinopathy, nephropathy, neuropathy, pulmonary defects, hepatic dysfunction, postoperative infections, tuberculosis, and even death (5).

Neopterin is a pteridine derivative, which is produced from guanosine triphosphate (GTP) by activated monocytes, macrophages, dendritic cells and endothelial cells. It is also produced in lesser amounts by the IFN- $\gamma$-stimulated renal epithelial cells, fibroblasts and vascular smooth muscle $(6-8)$. Neopterin levels have been shown to increase in conditions in which inflammation plays a role in the pathogenesis, as neopterin is an important indicator of monocyte activation in the inflammatory response. Therefore, studies have been conducted that investigate the role of neopterin in the development of diabetes in addition to inflammatory markers and in diabetes-related complications such as diabetic nephropathy and atherosclerosis (9-11).

In the present study, we aimed at evaluating the changes in serum neopterin concentrations in type 2 diabetes and the possible relationship between the levels of neopterin and diabetes.

\section{Materials and Methods}

\section{Setting and patients}

This retrospective study included a total of 139 individuals, among them 106 patients admitted to a family medicine outpatient clinic and diagnosed with type 2 diabetes and 33 healthy volunteers. The health status of all individuals in the control group was questioned in detail. Those who did not take any medication for four months prior to the study and who did not have any acute or chronic disease were included in the control group. All participants were informed about the study and written informed consent was obtained. The study was approved by the local Ethics Committee of Inonu University, Faculty of Medicine and was conducted in accordance with the principles of the Declaration of Helsinki.

All the participants in the study were questioned about age, medication use, smoking habits, and alcohol use. Patient groups were identified according to the diabetes diagnostic criteria of the ADA (12). A diagnosis of diabetes was established if plasma glucose levels were higher or equal to two of the following four values: according to OGTT results, fasting 5.27 $\mathrm{mmol} / \mathrm{L}$, 1 hour $10 \mathrm{mmol} / \mathrm{L}, 2$ hours $8.60 \mathrm{mmol} / \mathrm{L}$ and 3 hours $7.77 \mathrm{mmol} / \mathrm{L}$. Exclusion criteria were type 1 diabetes, inflammatory diseases, malignancy, metabolic diseases other than type 2 diabetes, kidney diseases, any acute or chronic infection, medication use, smoking, and other secondary systemic diseases accompanying type 2 diabetes.

\section{Neopterin measurement}

Blood samples were collected in shaded tubes, as neopterin is sensitive to light. Venous blood samples were centrifuged at 3,000 rpm for $10 \mathrm{~min}$ at $4{ }^{\circ} \mathrm{C}$ and then separated into sera. Serum samples were stored at $-20^{\circ} \mathrm{C}$ until analysis. No pretreatment was applied to the stored serum samples. According to the kit instruction, a sufficient amount of serum sample was pipetted directly onto the plate after dissolution. Neopterin was measured using commercially available enzyme-linked immunosorbent assay (ELISA) kits (DRG Diagnostics GmbH Marburg, Germany) with a minimum detectable concentration of $0.2 \mathrm{ng} / \mathrm{mL}$. The normal working range of this assay is between 0.3 and $3.0 \mathrm{ng} / \mathrm{mL}$. Serum neopterin levels were measured by ELISA according to the procedures recommended by the manufacturer. Analysis of neopterin by the ELISA method based on the competitive binding of unknown amounts of neopterin in serum samples and neopterin labeled with a constant amount of enzyme, to neopterin-specific antibodies immobilized on microtiter plates. After the washing step, the chromogenic substrate was added and color formation was observed. The enzymatic reaction (color intensity) was inversely proportional to the amount of neopterin in the sample. The reaction was ter- 


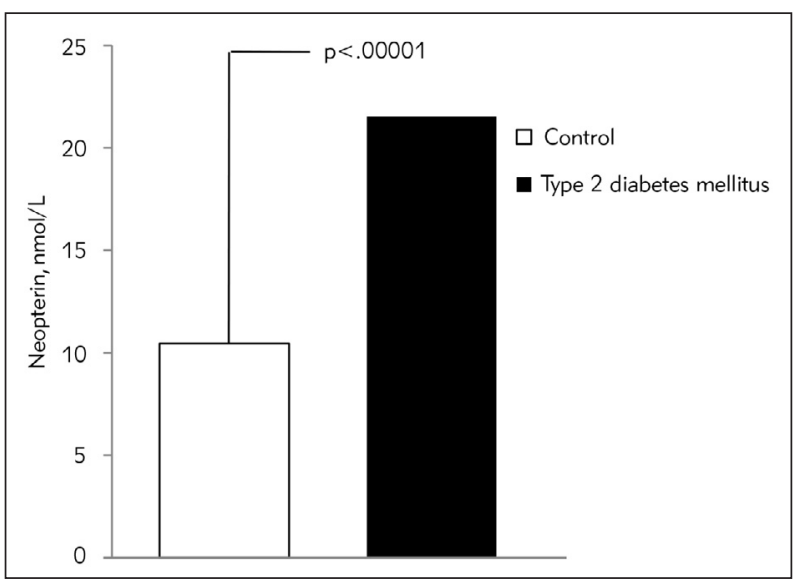

Figure 1 Neopterin concentrations in study groups.

minated by adding the reaction stopping solution. The optical density was measured at $450 \mathrm{~nm}$ with a microplate reader. All samples were examined twice. Serum neopterin levels were expressed in $\mathrm{nmol} / \mathrm{L}$.

\section{Statistical analysis}

Statistical analysis was performed using the Statistical.Package for Social Sciences 11.5 (SPSS) programme (SPSS Inc., Chicago, IL). Descriptive data were expressed in mean \pm standard error (SEM). Non-parametric Mann-Whitney $U$ test was used to compare independent groups. Inter-parametric correlations were analyzed using the Pearson correlation test. A $p$ value of $<0.05$ was considered statistically significant.

\section{Results}

There were 20 males and 13 females in the patient group and 68 males and 38 females in the control group. The mean age was $46.41 \pm 0.13$ years in the patient group and $50.21 \pm 0.32$ in the control group. Serum neopterin levels in healthy subjects showed an age-related increase and a decrease in the patient group, conversely. But, these correlations were not statistically significant.

Immune system dysfunction was associated with aging, and this age-related decrease in the patient group was thought to be the result of changes in immunomodulation.

The mean neopterin levels were 21.52 \pm 0.17 $\mathrm{nmol} / \mathrm{L}$ in type 2 diabetes patients and 10.45 $0.15 \mathrm{nmol} / \mathrm{L}$ in the control group (Figure 1). This diabetes-related increase was statistically significant $(p<0.00001)$. Diabetes was considered to lead to an increase in serum neopterin levels by activating the cellular immune system.

\section{Discussion}

Several studies have been conducted to investigate the pathological effects of diabetes on almost whole body physiology and to elucidate the different pathways of diabetes pathogenesis. Recent studies have shown that diabetes is associated with different pathologies and induces a number of diseases as well as the complications that it causes alone. Patients with diabetes are more susceptible to a variety of serious infections, and respiratory system complications such as tuberculosis (13-15). The incidence of infection in diabetics is higher than in those without diabetes. Although it is not yet clear which pathogenic mechanisms are responsible for this high risk of infection in diabetics, probable reasons include immune defects, increased adhesion of microorganisms to diabetic cells, the presence of micro/macroangiopathy or neuropathy, and the presence of numerous medical interventions in this group of patients (15).

Diabetes is defined as a risk factor for development of nervous system disorders such as Alzheimer's, schizophrenia, heart diseases, stroke, and cardiovascular disease (16-18). Based on all these studies, it can be concluded that diabetes is a syndrome which affects different body organs and leads to dysfunctions. Functional dysfunction in the organs results in diabetic morbidity, by significantly affecting the quality of life.

Neopterin is a non-specific marker of activated cell-mediated immunity. Changes in neopterin levels are helpful to estimate the severity of disease and therefore the prognosis more accurately. In several studies, increased serum and urine neopterin levels were used as a diagnostic or prognostic marker in various diseases. Neopterin levels have been reported to be elevated in many pathological conditions including systemic infections, autoimmune diseases, renal failure, glomerulonephritis, renal transplant rejection, insulin resistance, atherosclerosis, coronary artery disease, and diabetes. Neopterin is considered not only as an initial inflammatory marker, but also a predictive factor in the progression of the disease (19-22).

Since high neopterin levels are associated with production of reactive oxygen radicals and low antioxidant concentrations, neopterin can also be regarded as a sign of reactive oxygen species produced by the active cellular immune system. Consequently, neopterin measurements can predict not only the extent of cellular immune activation, but also the level of oxidative stress (8). The amount of secreted neopterin is strongly associated with the release of reactive oxygen radicals by the cells which reflects the level of oxidative stress caused by the activation of the immune system (23). Baris et al. (24) reported that serum and urine neopterin levels significantly increased in type 2 diabetic patients, compared to the control group. Also, high serum neopterin concentra- 
tions in diabetic patients with microalbuminuria suggest that neopterin, a monocyte activation marker, correlates with renal dysfunction in patients with type 2 diabetes. There are also study results which found the contrary of this result. In a study comparing macrophage activation in both types of diabetes, no increased macrophage activation in type 2 diabetes, as opposed to type 1 diabetes, was found and, consequently, high plasma neopterin levels were not found (22). Neopterin levels have also been evaluated in gestational diabetes, which is another type of diabetes. Serum neopterin levels in patients with gestational diabetes were reported to be higher than in pregnant women without diabetes (25).

The nitric oxide precursor, L-arginine, is involved in a variety of pathologies, including type 2 diabetes and its complications. Therefore, it is critical to evaluate the early markers of inflammation and endothelial functions, such as L-arginine and neopterin, in type 2 diabetic patients $(20,22,24)$.

In conclusion, activation of the immune system plays a key role in a variety of diseases, such as infections, neurological diseases, autoimmune diseases, cardiovascular diseases and malignancies, or in cases of allograft transplantation. It is, thus, of utmost

\section{References}

1. World Health Organisation. Global report on diabetes. ISBN 978-92-4-156525-7. 2016. Available from: http://apps.who.int/iris/bitstream/10665/204871/ 1/9789241565257_eng.pdf.

2. Definition and diagnosis of diabetes mellitus and intermediate hyperglycemia: report of a WHO/IDF consultation. Geneva: World Health Organization 2006. P. 21. ISBN 978-92-4-159493-6.

3. American Diabetes Association. Standards of medical care in diabetes-2011. Diabetes Care 2011; 34(1): 1161.

4. Ozougwu JC, Obimba KC, Belonwu CD, Unakalamba $\mathrm{CB}$. The pathogenesis and pathophysiology of type 1 and type 2 diabetes mellitus. J Physiol Pathophysiol 2013; 4(4): 46-57.

5. Kumar A, Bharti SK, Kumar A. Type 2 diabetes mellitus: The concerned complications and target organs. Apollo Med 2014; 1(3): 161-6.

6. Eisenhut M. Neopterin in diagnosis and monitoring of infectious diseases. J Biomark 2013; 2013: 196432.

7. Widner B, Leblhuber F, Fuchs D. Increased neopterin production and tryptophan degradation in advanced Parkinson's disease. J Neural Trans 2002; 109(2): 1819.

8. Murr C, Widner B, Wirleitner B, Fuchs D. Neopterin as a marker for immune system activation. Curr Drug Metab 2002; 3(2): 175-87. importance to evaluate the immunological changes in patients by using early and sensitive markers to decide the most appropriate treatment options in different pathologies. Therefore, the progression of the disease can be monitored easily and sensitively by evaluating the levels of neopterin in biological fluids such as serum, urine, saliva, cerebrospinal fluid, synovial fluid and pancreatic fluid, which is a cellular immune activation marker. The biological resistance of neopterin as a biomarker contributes to its use as a prognostic marker in many pathologies. In the current study, we found a significant increase in neopterin levels in patients with type 2 diabetes, compared to the control subjects, due to the activation of the cellular immune system. Based on this result, we highlight that immune system activation plays a role in the pathogenesis of type 2 diabetes, however, further studies are required to establish a definite conclusion.

\section{Acknowledgments: None.}

\section{Conflict of interest statement}

The authors stated that they have no conflicts of interest regarding the publication of this article.

9. Weiss G, Widner B, Zoller H, Schobersberger W, Fuchs $D$. Immune response and iron metabolism. Br J Anaesth 1998; 81(1): 6-9.

10. Vengen IT, Dale AC, Wiseth R, Midthjell K, Videm V. Neopterin predicts the risk for fatal ischemic heart disease in type 2 diabetes mellitus: long-term follow-up of the HUNT 1 study. Atherosclerosis 2009; 207(1): 23944.

11. Grammer TB, Fuchs D, Boehm BO, Winkelmann BR, Maerz W. Neopterin as a predictor of total and cardiovascular mortality in individuals undergoing angiography in the Ludwigshafen Risk and Cardiovascular Health study. Clin Chem 2009; 55(6): 1135-46.

12. American Diabetes Association. Standards of medical care in diabetes - 2008. Diabetes Care 2008; 31(1): 12-54.

13. Baghaei $P$, Marjani $M$, Javanmard $P$, Tabarsi $P$, Masjedi MR. Diabetes mellitus and tuberculosis: facts and controversies. J Diabetes Metab Disord 2013; 12(1): 58.

14. Jeon CY, Murray MB. Diabetes mellitus increases the risk of active tuberculosis: a systematic review of 13 observational studies. PLoS Med 2008; 5(7):e152.

15. Geerlings SE, Hoepelman Al. Immune dysfunction in patients with diabetes mellitus (DM). FEMS Immunol Med Microbiol 1999; 26(3-4): 259-65.

16. Holt RI. Diagnosis, epidemiology and pathogenesis of diabetes mellitus an update for psychiatrists. Br J Psychiatry Suppl 2004; 47: 55-63. 
17. Sridhar GR, Lakshmi G, Nagamani G. Emerging links between type 2 diabetes and Alzheimer's disease. World J Diabetes 2015; 6(5): 744-51.

18. Centers for Disease Control and Prevention. National diabetes fact sheet: national estimates and general information on diabetes and prediabetes in the United States, 2011. Atlanta, GA: U.S. Department of Health and Human Services, Centers for Disease Control and Prevention; 2011.

19. Avcı E, Coskun S, Cakır E, Kurt Y, Akgul EO, Bilgi C. Relations between concentrations of asymmetric dimethylarginine and neopterin as potential risk factors for cardiovascular diseases in hemodialysis-treated patients. Ren Fail 2008; 30(8): 784-90.

20. Siasos G, Tousoulis D, Antoniades C, Stefanadi E, Stefanadis C. L-Arginine, the substrate for NO synthesis: an alternative treatment for premature atherosclerosis? Int J Cardiol 2007; 116(3): 300-8.

21. Collinson P. Laboratory medicine is faced with the evolution of medical practice. J Med Biochem 2017; 36: 211-5.
22. Anwaar I, Gottsäter A, Eriksson KF, Jacobsson L, Lindgärde F, Mattiasson I. Increased plasma endothelin-1 and intraplatelet cGMP in men with disturbed glucose metabolism. Diabetes Res Clin Pract 2000; 50(2): 12736.

23. Weiss MF, Rodby RA, Justice AC, Hricik DE. Free pentosidine and neopterin as markers of progression rate in diabetic nephropathy. Collaborative Study Group. Kidney Int 1998; 54(1): 193-202.

24. Baris N, Erdogan M, Sezer E, Saygili F, Mert Ozgonul A, Turgan $\mathrm{N}$, et al. Alterations in L-arginine and inflammatory markers in type 2 diabetic patients with and without microalbuminuria. Acta Diabetol 2009; 46(4): 309-16.

25. Ipekci SH, Kebapcilar AG, Yilmaz SA, Ilhan TT, Pekin AT, Abusoglu S, et al. Serum levels of neopterin in gestational diabetes mellitus: the relationship with Apgar Scores. Arch Gynecol Obstet 2015; 292(1): 103-9.

Received: December 20, 2017

Accepted: February 12, 2018 